\title{
Elena Procario-Foley and Robert Cathey, Eds. Righting Relations After the Holocaust and Vatican II
}

\author{
(New York: Paulist Press, 2018), paperback, xxvi + 334 pp.
}

\author{
JAY MOSES \\ pastorjaym@sbcglobal.net \\ Hope Presbyterian Church, Wheaton, Illinois 60189
}

At a time when our distance from the groundbreaking encyclical Nostre Aetate and Vatican II increases, and when the expressions of dignity towards groups constituting "the other" are dangerously deteriorating, the task of remembering and building upon the work of those who have made historic contributions toward the reconciliation of estranged groups is paramount. Rev. Dr. John Pawlikowski, through his tireless efforts in Jewish-Catholic relations, is certainly one of those names. The collection of essays in the edited volume Righting Relations After the Holocaust and Vatican II both highlights Pawlikowski's half-century of work and offers sophisticated discussions of many salient topics in contemporary relations. It is suffused with a commitment to the ethical imperative of the imago dei we are in constant danger of losing.

The book, edited by Robert Cathey from McCormick Theological Seminary and Elena Procario-Foley from Iona College, is divided into three thematic sections (Ethics and Theology, Holocaust Studies, and Interreligious Studies) in an attempt to encompass the areas in which Pawlikowski's work has had great influence. For the most part these divisions help frame this collection of discussions, though some contributors venture outside this frame. A review of a collection of such diverse material is a complex enterprise, but in the case of this work, the fruits it yields and the wisdom it contains is well worth the attempt.

The first section collects a group of essays under the theme of Ethics and Theology. It includes discussions of the framework and foundations of Pawlikowski's thought. Drawing on theologians such as Karl Barth and Peter Hodgson and ethicists such as Reinhold Niebuhr and Emmanuel Levinas, the contributors demonstrate Pawlikowski's lifelong examination of concepts such as "Love of Neighbor as Self" and "The Common Good." Two chapters specifically highlight important theological insights and emphases in his work: Cathey's chapter "Pawlikowski's Christology as Challenge to Reformed Christology" and Michael S. Kogan's chapter "Welcoming Jesus Home." Building on Pawlikowski's ideas 
(like many of the contributors), Cathey helpfully formulates some theses in Jewish-Christian dialogue regarding the place of Jesus, and with it, an adequate Christology. He helpfully highlights two observations from Pawlikowski's writings. First, a focus on the incarnation offers the best option for developing a Christology that allows for continued covenantal inclusion of the Jewish People. Second, the challenge in Christology is to integrate the interiority of Christian experience with the exteriority of historical awareness, or, as Pawlikowski states it, to affirm the "presence of the kingdom within human consciousness and in history," which includes viewing Jesus in his historical context (p. 24).

In the post-Nostra Aetate world, there have been many (mostly Christian) attempts to build theological bridges between early Christianity and ancient Judaism. Some have found it useful to explore Jewish liturgical sources when considering the Christ event (and especially themes of sacrifice and atonement). Others have found bridges of interreligious understanding in different forms of a prophetic Christology that sees similarities in Jewish and Christian hermeneutics. Pawlikowski has been unique in his emphasis on one area that might seem to be the last place of constructive dialogue between the two traditions: the presence of God within the human (i.e., the incarnation). Cathey helpfully extrapolates from recent theologians the basic if counter-intuitive contribution by Pawlikowski: Only the incarnation leaves room for the continued place of Judaism within Christianity's theology; others approaches yield scenarios of Christian triumphalism and fulfillment. Speaking within his own Presbyterian context, Cathey quotes from a recent document "In Our Time': A Statement on Relations Between the Presbytery of Chicago and the Jewish Community in Metropolitan Chicago." (He was one of its authors.) He recognizes the gifts of the Jewish tradition to Christianity and finds room for Christians to value and explore a living Judaism. Such interaction "humbles...reminds...preserves...grounds...provokes...sustains... and awakens Christians to our relationship and bond with Jews" (p. 40).

"Welcoming Jesus Home" by Kogan, a Jewish philosopher and theologian, considers what constitutes an adequate Christology for Christian-Jewish dialogue. Kogan has written extensively on Jewish views of religious pluralism and takes Pawlikowski's challenge for a new Jewish "place" for Jesus in Jewish history and understanding seriously. Accepting Pawlikowski's suggestion of the incarnation as a fruitful place, Kogan writes, "I am suggesting that Jesus' role for a Judaism willing to re-admit him would be as a 'son of man', a representative human being who reveals the divinity in all of us humans. He shows us clearly who we are" (p. 89). Exploring the incarnational impulse of a divine-human mutuality, he continues, "I am writing to Jews. I believe that if we focus on the issue of the dual nature we share with Jesus, this could be a bridge between our two faiths, as long as we remember that what is true of him is true of all of us. Every 'son of man' possesses divine as well as human aspects" (p. 90). Kogan encourages current Jews to take the insights of "Second temple expressions" of Jesus' unique Godconsciousness as a mirror needed for all of "the divine aspects of every person." He powerfully concludes that "Jesus was a Jew, one of our own. He should no longer remain a stranger to our, and his, Jewish faith" (p. 92). Kogan's chapter 
demonstrates the richness of including Jewish partners in Christian theological dialogue.

The next series of chapters is focused around the study of the Holocaust. Contributors consider its causes, sociological context, and present relevance. Pawlikowski's keen ethical thought and call for responsibility (perhaps partly a reflection of his Polish-American identity) have made him relentless in grappling with the theological implications of the event. The authors touch on such subjects as pedagogy (Carol Rittner), memory (Katharina von Kellenbach), and "righteous Gentiles" (Stephen Leonard Jacobs). The following two chapters touch upon important applications of Holocaust studies in our day. In "The Ethics of Interfaith Post-Holocaust Engagement," Victoria Barnett examines the intersection of two areas at the foundation of Pawlikowski's work: genocide studies and interreligious dialogue. Barnett starts by pondering the dangers of generalizing such specific tragedies as the Holocaust to glean universalized, interreligious principles: "Would an expansion detract from or even undermine the specific nuances of the Jewish-Christian relationship? With regard to Holocaust history, does such engagement open the door to distortion, false analogies, or even minimizing the nature of the Holocaust?" (p. 142). Nonetheless, Barnett cautiously affirms the venture, and after an initial affirmation of the specificity of the Holocaust, concludes that what can be learned for the sake of interfaith engagement is the role of historic tragedies in the stories of different peoples. For different religious traditions to truly engage each other in the context of the real world, participants must begin the "examination of a long and painful theological history" (p. 148). Interreligious dialogue can be a tool for reconciliation when discussions about historic ethical failure are used to "open the way for theological and ethical reflection" (p. 150). In this way interreligious dialogue can aid an exploration of the historical causes of conflict and their partial resolution, while theology can aid an ethical exploration. This type of approach to interreligious dialogue can already be see in dialogues between American Christians and the Native Americans, between Sikhs, Hindus and Muslims on the Indian sub-continent, and between Orthodox Christians and Muslims in the Middle East and Turkey. The excavation of theologies and ideologies used to encourage violence, oppression, ethnic cleansing, and genocide can benefit from the inclusion of lessons learned from JewishChristian dialogue (especially regarding the Holocaust).

Flowing naturally from this insight is the contribution by Mehnaz M. Afridi, "Muslim Memory and Righting Relations with the Other." Though Pawlikowski has spent much of his life working for reconciliation and better relations between Jews and Christians, Afridi shows that his insights have broader relevance. Writing of Muslims' examining conflicts with the Jewish community, she draws on Pawlikowski's views of the so-called "imaging" of the other present among Christians in Nazi Germany: "I focus on the word imagine because so much of the 'religion on the [Muslim] street' stems from political and historical memory and myths" (p. 157). She continues in regards to Muslim perspectives on the Holocaust: "The Holocaust was minimized and relativized because of the parallels made to Palestinian suffering and the many wars in the Middle East. The imagi- 
nation of such myths can lead to more distance and less understanding” (p. 162). Like Pawlikowski's confession of Christian complicity in the teaching of contempt, Mehnaz adopts a "model of deep self-critique" and recognizes that "Muslims were not innocent or pure during the advent of Islam nor in the treatment of minorities" (p. 169). She also remarks that "accepting the deep holes within one's theology and accepting responsibility for past and present acts of violence" is a practice worthy of emulation and respect. This chapter, the only one not by a Jew or a Christian, offers a powerful demonstration of a form of metanoia.

The final section, Interreligious Studies, contains relatively more diverse material. This final grouping seeks to focus specifically on the Roman Catholic contribution to Jewish-Christian relations. Found here are chapters spanning Pawlikowski's interest in the reform of liturgy (Ruth Langer), the role of Jewish participation in Vatican II (Susannah Heschel), and the survival of Jewish identity within a majority non-Jewish world (Carmen M. Nanko-Fernandez and JeanPierre M. Ruiz). Two other chapters within this section, "Nostra Aetate, Omnia Mutantur: The Times They Are a-Changing" by Amy-Jill Levine and "Learning from the Other: The Nostra Aetate Trajectory Our Time" by Mary C. Boys, encapsulate well the current state of Jewish-Christian relations.

Amy-Jill Levine, a prominent Jewish voice in Jewish-Christian dialogue today, gives an incisive examination and critique of changes in the Catholic Church's presentation of Judaism. After listing many positive features in Catholic statements over the last few decades, she notes the presence of some troubling oversimplifications and distortions. For example, she finds this view present: "Jesus was killed because he was nice to women, eschewed purity, dined with tax collectors, condemned slavery, and offered free medical care" (p. 233). She charitably sees presentations of Judaism as a negative foil to presentations of Jesus as "not based in hatred but as primarily indicators of educational failures." Many of her critiques echo more detailed explorations in her work The Misunderstood Jew: The Church and the Scandal of a Jewish Jesus (2007). Here, as there, she reveals shortcomings of liberation theology when applied to the ancient Jewish / early Christian period. Her strongest remarks are reserved for her review of the annotated footnotes of the Bible translation promoted by the U.S. Conference of Catholic Bishops, the New American Bible Revised Edition (from 2011). After a few comments on specific passages of Jewish-Christian importance, she confesses that the annotations are at best "uninformed" (p. 338) or, stated more baldly, "do damage" (p. 242). She encourages Christians to learn from Jewish traditions when interpreting the Old and New Testament. Despite these critiques, her attitude is hopeful, and she also offers constructive guidance.

Boys recounts the fascinating stories of two converts to Catholicism, John Oesterreicher (a convert from Judaism) and Karl Thieme (a convert from Lutheranism). Boys emphasizes the importance of these men's life experiences in shaping their theological views and in influencing their participation in Catholic discussions of Judaism. Oesterreicher's traditional Jewish upbringing gave him an intimate understanding of Catholic misconceptions of and contempt for Jews and 
Judaism and led him to challenge Church teachings. Thieme's experience of life under Nazism and Lutheran background gave him great sensitivity regarding bigotry, contempt, and hatred for Jews found within Christian theology. Both had intimate familiarity, one with Jewish life, the other with Christian contempt, that prompted them to try to challenge traditional anti-Jewish teachings. The theological breakthrough for both focused upon their new readings of Romans 9-11, which has emerged as a major focus of contemporary Christian theologies of Judaism. Nonetheless, change was not immediate, especially for prominent topics such as evangelism. Boys states that "it is misleading to think that the church can simply flip a theological switch" to change such long seated perspectives of the religious "other" (p. 299). On many issues, the changes begun by the daring drafters of Nostre Aetate have only slowly born fruit. Boys prophetically turns her gaze from the past to our present and sees a missed opportunity to learn from issues raised at Vatican II today, a time of heightened "aversion to difference" and "reversion to tribalism." There is a wisdom relevant to today in the discussions held many years ago.

There is a consistently high level of sophistication in these chapters, a sharing of gifts gleaned from decades of hard work in Jewish Christian dialogue. It is heartening to realize that the presence of Jewish contributors to this theological discussion, all honoring the work of John Pawlikowski, is something that would have been unlikely 25 years ago, let alone with such palpable feelings of trust and friendship across the religious divide. Yehezkel Landau, in one of the last chapters, underscores Pawlikowski's contribution: "As ethnic and religious loyalties assert themselves in increasingly polarized ways, all people of faith must join forces to safeguard human dignity and equality, the imperative that John rightfully insists remain central in our minds, hearts and actions" (p. 321). 